Article

\title{
The Correlation of Maternal Factors and The Quality of Antenatal Care Services With Low Birth Weight Babies In Health Facilities Level I
}

\author{
Wira Meiriza ${ }^{1}$, Aladin $^{2}$, Edison $^{3}$ \\ ${ }^{1}$ Midwifery, Faculty of Medicine, Andalas University, Padang City \\ ${ }^{2}$ Public Health, Faculty of Medicine, Andalas University, Padang City \\ ${ }^{3}$ Public Health, Faculty of Medicine, Andalas University, Padang City
}

\begin{tabular}{l}
\hline SUBMISSION TRACK \\
\hline Recieved: March 28, 2018 \\
Final Revision: May 03, 2018 \\
Available Online: May 15, 2018 \\
KEYWORDS \\
\hline LBWB, Maternal Factors, Quality of Antenatal \\
Care Services \\
CORRESPONDENCE \\
\hline
\end{tabular}

Phone: 085364070593

E-mail: m_wira@ymail.com

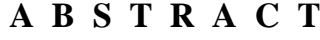

Infant Mortality Rate in West Sumatra still increased from 96 cases in 2015 becomes 111 cases in 2016. One of the contributors to this was the case of Low Birth Weight Babies (LBWB), wich is birth weight $<2500$ grams. Causative factors of LBWB are derived from maternal factors because it is related to fetal growth, starting from the moment of conception until the baby is born. Maternal health is very influential towards the growth and development of the fetus. In addition, Antenatal Care is also require to monitor maternal health. Antenatal service care quality can detect the occurrence of risk in pregnancy. This study aims to determine the relationship of maternal factors based on maternal age, parity, distance of pregnancy, complications of pregnancy, economic status, nutritional status, anemia status, antenatal care implementation and the quality of antenatal care services with LBWB incidence on health facilities level 1 in Padang City.
\end{abstract}

This study used a comparative cross-sectional design totalling 72 respondents consisting of a group of mothers who gave birth to babies with birth weight $<2500$ grams and $\geq 2500$ grams using consecutive sampling technique. Then conducted interviews and observations by using questionnaires as well as data processing were carried out using SPSS. The results showed there was a correlation between pregnancy complications ( $p=0.033)$, anemia status $(\mathrm{p}=0.016)$ and the implementation of antenatal care $(\mathrm{p}=$ 0.000 ) with the incidence of LBWB, while the unrelated were maternal age $(p=0.405)$, parity $(p=1,000)$, pregnancy distance $(\mathrm{p}=1,000)$, economic status $(\mathrm{p}=0.637)$, nutritional 
status ( $\mathrm{p}=0.326)$, and quality of antenatal care services ( $\mathrm{p}=$ 0.812). The conclusion of this study is that there is no correlation between the quality of antenatal care services and the incidence of LBWB, and the implementation of antenatal care is the dominant factor related with the incidence of LBWB in Padang City.

\section{INTRODUCTION}

Infants with low birth weight areoften experienced health problems, by some people with birth weight less than 2500 grams and is the largest component of neonatal and infant mortality rates. LBWB is a major risk factor in neonatal morbidity and mortality indeveloping countries and provide a long-term impact on their lives in the future (Nelson, 2000).

In the year 2013 the rate of LBWB in Indonesia slightly decreased, from $11.1 \%$ in 2010 to $10.2 \%$, with the highest percentage is in Central Sulawes Province $(16.8 \%)$ and the lowest is in North Sumatra Province (7.2\% ) (Riskesdas, 2013). In Padang City, the number of LBWB have increased from $1.7 \%$ or amounting to 297 babies in 2014 to $2.17 \%$ or by 371 babies in 2015, while in 2016 the number of LBWB has decreased becoming 351 cases $(2.06 \%)$ (Padang City Health Office in 2015 and 2016). The results of the initial survey that have been conducted in Dr. Rasidin Hospital Padang obtained that out of 270 laborthat are on Midwifery Ward in 2016 there were 29 cases $(10.7 \%)$ of LBWB.

The cause of LBWB occurrence is generally multifactorial. One of the factors that affect the occurrence of LBWB is maternal factors. Maternal factors are associated with fetal growth, starting from the moment of conception until the baby is born. Maternal health is very influential towards the growth and development of the fetus. Therefore, attention to the health of pregnant women is urgently needed in order for the fetus can be born in a healthy state with normal weight and can grow and develop optimally. In addition, births that are too young, too tight, too much and too old add to the poor health and nutrition conditions of pregnant women (Maryanti, 2011).

Antenatal Care is an important way to monitor and support the health of normal pregnant women and detect mothers with normal pregnancy. Pregnancy examination also serves to detect various problems related to pregnancy that often arise during pregnancy, and also to be able to avoid highrisk pregnancy (Saifuddin, 2007).

Antenatal care is a service by health workers for mothers during their pregnancy that are carried out in accordance with the standards of defined antenatal care. Newborn mortality rates in children whose mothers getting antenatal care and delivery assistance by medical professionals are one-fifth of the mortality rate in children whose mothers did not receive this service (UNICEF Indonesia, 2012). Antenatal health services are also part of $\mathrm{MCH}$ services (Maternal and Child Health) (Ministry of Health, 2010). To assess the quality of $\mathrm{MCH}$ services, facilitative supervision activities need to be carried out with the aim of assessing compliance with $\mathrm{MCH}$ service standards carried out by midwives or health workers in the field, followed by a quality improvement process at the assessed health care facilities. Quality maternal and newborn health services can prevent high mortality.

According to WHO in the Global Nutrition Targets 2025 also mentions that to reduce the incidence of LBWB, one of the interventions conducted is antenatal care interventions for all women so that there is monitoring of fetal growth. One of the component of maternal health services is the granting of iron substance. Iron has a vital role against fetal growth. During pregnancy, iron intake must be added considering during pregnancy, the blood volume in the mother's body increases. 
So that to be able to continue to meet the needs of the mother and supply of food and oxygen in the fetus through the placenta, more iron intake is needed. Iron deficiency can cause pregnant women to suffer from anemia. Anemia is one of the risks of maternal mortality, the incidence of babies with LBWB, infection of the fetus and mother, miscarriage, and premature birth (Ministry of Health RI, 2016)

Various studies mentioned about the factors that influence the incidence of LBWB. One of them is the antenatal care factor in Simarmata's study (2010), that pregnant women who receive poor quality of antenatal care are likely to be at risk of developing LBWB 2,22 times compared to pregnant women who receive good quality antenatal care.

Based on the description above, because there is still a high rate of temporary LBWB that does not match the coverage of $\mathrm{K} 1$ and K4 that has exceeded the target achievement, besides the need to examine maternal factors that affect fetal health, then author interested to see the correlation of maternal factors and antenatalcare quality with the incidence of low birth weight babies in Padang health facilities level I.

\section{METHODS}

This was analytical survey study with comparative cross-sectional design. This study conducted on the existing health facilities in Padang City and from July 2017 - June 2018. The population of the study was all mothers who gave birth to babies with birth weight $<2500$ grams (LBWB) while the control population was all mothers who gave birth to babies with birth weight $\geq 2500$ grams. The sample in this study is the population that meets the inclusion and exclusion criteria.

Bivariate analysis used Chi Square test with significance level $\alpha=0.05$. If $\rho$ value $\leq \alpha$ 0.05 means that there is a significant relationship between the independent variable and the dependent variable and if $\rho$ value $>\alpha 0.05$ means there is no meaningful relationship. Furthermore, to determine the closeness of the relationship between the independent variable and the dependent variable, the Contingency Coefficient value (C) is calculate

\section{RESULT}

Frequency distribution of respondents based on education level can be seen in Table 1 below:

Table 1. Frequency distribution of respondents based on education level

\begin{tabular}{lllll}
\hline \multirow{2}{*}{\multicolumn{1}{c}{ Education }} & \multicolumn{2}{c}{ NBWB } & \multicolumn{2}{c}{ LBWB } \\
\cline { 2 - 5 } & f & $\mathbf{\%}$ & f & \% \\
\hline Finished Elementary & 2 & 5,6 & 7 & 19,4 \\
Finished JHS & 5 & 13,9 & 4 & 11,1 \\
Finished SHS & 19 & 52,8 & 22 & 61,1 \\
Finished College & 10 & 27,8 & 3 & 8,3 \\
\hline
\end{tabular}

Based on Table 1 it is known that more than half of mothers who have Low Birth Weight Babies (LBWB) the level of their education are senior high school $(61.1 \%)$, as well as mothers who have a Normal Birth Weight Babies (NBWB), there are more than half of the mother's education level is senior high school $(52.8 \%)$.

Table 2. Frequency Distribution of Respondents by Type of Work

\begin{tabular}{lcccc}
\hline \multirow{2}{*}{\multicolumn{1}{c}{ Type of Work }} & \multicolumn{2}{c}{ NBWB } & \multicolumn{2}{c}{ LBWB } \\
\cline { 2 - 5 } & $\mathbf{f}$ & $\boldsymbol{\%}$ & $\mathbf{f}$ & $\boldsymbol{\%}$ \\
\hline Teacher & 3 & 8,3 & 0 & 0 \\
Honorary Employees & 1 & 2,8 & 2 & 5,6 \\
Housewife & 24 & 66,7 & 29 & 80,6 \\
Government Employees & 1 & 2,8 & 0 & 0 \\
Police Women & 0 & 0 & 1 & 2,8 \\
Private Sector Worker & 7 & 19,4 & 4 & 11,1 \\
\hline
\end{tabular}

Based on Table 2 it is known that the type of work that is owned by respondents is mostly as housewives, both for mothers who have LBWB (80.6\%) and for mothers who have NBWB $(66.7 \%)$.

Table 3. The Correlation of Maternal Age with the Incidence of Low Birth Weight Babies

\begin{tabular}{cccccccc}
\hline \multirow{2}{*}{$\begin{array}{c}\text { Maternal } \\
\text { Age }\end{array}$} & \multicolumn{2}{c}{ NBWB } & \multicolumn{2}{c}{ LBWB } & \multicolumn{2}{c}{ Total } & \\
\cline { 2 - 6 } & f & $\%$ & f & $\%$ & f & $\%$ & \% \\
\hline At Risk & 29 & 52,7 & 26 & $\begin{array}{r}47 \\
, 3\end{array}$ & 55 & 100 & 0,4 \\
& & & & 58 & & & 05 \\
Not at Risk & 7 & 41,2 & 10 &, 8 & 17 & 100 & \\
\hline
\end{tabular}


Based on Table 3, the percentage of LBWB was higher in maternal age at risk $(58.8 \%)$ compared to maternal age not at risk (47.3\%). Statistically there was no significant relationship ( $>$ > 0.05) between maternal age and the incidence of LBWB.

Table 4. The Relationship of Parity with the Incidence of Low Birth Weight Babies

\begin{tabular}{|c|c|c|c|c|c|c|c|}
\hline \multirow{2}{*}{ Parity } & \multicolumn{2}{|c|}{ NBWB } & \multicolumn{2}{|c|}{ LBWB } & \multicolumn{2}{|c|}{ Total } & \multirow{2}{*}{$\mathbf{p}$} \\
\hline & $\mathbf{f}$ & $\%$ & $\mathbf{f}$ & $\%$ & $\mathbf{f}$ & $\%$ & \\
\hline Low & 34 & 50 & 34 & 50 & 68 & 100 & 1,000 \\
\hline High & 2 & 50 & 2 & 50 & 4 & 100 & \\
\hline
\end{tabular}

Based on Table 4, the percentage of LBWB was the same between mothers with low parity (50\%) and with mothers with high parity $(50 \%)$. Statistically there was no significant relationship ( $>>0.05$ ) between maternal parity and the incidence of LBWB.

Table 5. The Relationship Between Pregnancy Distance and the Incidence of Low Birth Weight Babies

\begin{tabular}{lcccccccc}
\hline \multirow{2}{*}{$\begin{array}{l}\text { Pregnanc } \\
\text { y Distance }\end{array}$} & \multicolumn{2}{c}{ NBWB } & \multicolumn{2}{c}{ LBWB } & \multicolumn{2}{c}{ Total } & \\
\cline { 2 - 5 } & f & $\%$ & f & $\%$ & f & $\%$ & p \\
\hline $\begin{array}{l}\text { Not at } \\
\text { Risk }\end{array}$ & 34 & 50 & 34 & 50 & 68 & 100 & 1,000 \\
At Risk & 2 & 50 & 2 & 50 & 4 & 100 & \\
\hline
\end{tabular}

Based on Table 5, the percentage of LBWB was the same between mothers with a nonrisky pregnancy distance $(50 \%)$ with mothers who had a risky pregnancy distance $(50 \%)$. Statistically there was no significant relationship ( $p>0.05$ ) between the distance of pregnancy and the incidence of LBWB.

Table 6. The Relationship of Pregnancy Complications with the incidence of Low Birth Weight Babies

\begin{tabular}{|c|c|c|c|c|c|c|c|c|}
\hline \multirow{2}{*}{$\begin{array}{c}\text { Pregna } \\
\text { ncy } \\
\text { Compli } \\
\text { cation }\end{array}$} & \multicolumn{2}{|c|}{ NBWB } & \multicolumn{2}{|c|}{ LBWB } & \multicolumn{2}{|c|}{ Total } & \multirow[t]{2}{*}{$\mathbf{p}$} & \multirow[t]{2}{*}{$\mathbf{C}$} \\
\hline & $\mathbf{f}$ & $\%$ & f & $\%$ & f & $\%$ & & \\
\hline $\begin{array}{l}\text { There } \\
\text { isn't }\end{array}$ & 21 & $\begin{array}{r}63 \\
6\end{array}$ & 12 & $\begin{array}{r}36 \\
, 4\end{array}$ & 33 & 100 & $\begin{array}{c}0,03 \\
3\end{array}$ & $\begin{array}{c}0, \\
24 \\
3\end{array}$ \\
\hline There & & 38 & & 61 & & & & \\
\hline is & 15 &, 5 & 24 &, 5 & 39 & 100 & & \\
\hline
\end{tabular}

Based on Table 6, the percentage of LBWB was higher in mothers who experienced pregnancy complications $(61.5 \%)$ compared to mothers who did not experience pregnancy complications (36.4\%). Statistically there was a significant relationship ( $\mathrm{p}<0.05$ ) between pregnancy complications with the incidence of LBWB. Contingency coefficient value is 0.243 which shows that the relationship between variables is weak.

Table 7. The Relationship of Economic Status with the Incidence of Low Birth Weight Babies

\begin{tabular}{|c|c|c|c|c|c|c|c|}
\hline \multirow{2}{*}{$\begin{array}{l}\text { Economi } \\
\text { c Status }\end{array}$} & \multicolumn{2}{|c|}{ NBWB } & \multicolumn{2}{|c|}{ LBWB } & \multicolumn{2}{|c|}{ Total } & \multirow[t]{2}{*}{$\mathbf{p}$} \\
\hline & $\mathbf{f}$ & $\%$ & $\mathbf{f}$ & $\%$ & f & $\%$ & \\
\hline \multirow{3}{*}{ High } & & 52 & & 47 & 34 & 100 & \multirow{4}{*}{0,637} \\
\hline & 18 & ,9 & 16 &, 1 & & 100 & \\
\hline & & 47 & & 52 & 38 & & \\
\hline Low & 18 &, 4 & 20 & ,6 & & 100 & \\
\hline
\end{tabular}

Based on Table 7, the percentage of LBWB was higher at low economic status $(52.6 \%)$ compared to high economic status (47.1\%). Statistically there was no significant relationship ( $p>0.05$ ) between economic status and the incidence of LBWB.

Table 8. The Relationship between Nutritional Status with the Incidence of Low Birth Weight Babies

\begin{tabular}{|c|c|c|c|c|c|c|c|}
\hline \multirow{2}{*}{$\begin{array}{c}\text { Nutrit } \\
\text { ional } \\
\text { Status }\end{array}$} & \multicolumn{2}{|c|}{ NBWB } & \multicolumn{2}{|c|}{ LBWB } & \multicolumn{2}{|c|}{ Total } & \multirow[t]{2}{*}{$\mathbf{p}$} \\
\hline & $\mathbf{f}$ & $\%$ & $\mathbf{f}$ & $\%$ & $\mathbf{f}$ & $\%$ & \\
\hline Good & 32 & $\begin{array}{c}52, \\
5\end{array}$ & 29 & $\begin{array}{r}47 \\
5\end{array}$ & 61 & 100 & $\begin{array}{c}0,32 \\
6\end{array}$ \\
\hline Poor & 4 & $\begin{array}{c}36 \\
4\end{array}$ & 7 & $\begin{array}{r}63 \\
6\end{array}$ & 11 & 100 & \\
\hline
\end{tabular}

Based on Table 8, the percentage of LBWB was higher in poor nutritional status $(63.6 \%)$ compared to good nutritional status (47.5\%). Statistically there was no significant relationship ( $p>0.05$ ) between nutritional status and the incidence of LBWB. 
Table 9. The Relationship of Anemia Status with the Incidence of Low Birth Weight Babies

\begin{tabular}{|c|c|c|c|c|c|c|c|c|}
\hline $\begin{array}{c}\text { Ane } \\
\text { mia } \\
\text { Statu }\end{array}$ & \multicolumn{2}{|c|}{ NBWB } & \multicolumn{2}{|c|}{ LBWB } & \multicolumn{2}{|c|}{ Total } & \multirow{2}{*}{$\mathbf{p}$} & \multirow{2}{*}{ C } \\
\hline $\mathbf{S}$ & f & $\%$ & f & $\%$ & f & $\%$ & & \\
\hline $\begin{array}{c}\text { Non- } \\
\text { Anem } \\
\text { ia }\end{array}$ & 27 & $\begin{array}{r}61 \\
, 4\end{array}$ & 17 & $\begin{array}{l}38 \\
6\end{array}$ & 44 & 100 & $\begin{array}{c}0,01 \\
6\end{array}$ & $\begin{array}{l}0,2 \\
74\end{array}$ \\
\hline $\begin{array}{c}\text { Anem } \\
\text { ia }\end{array}$ & 9 & $\begin{array}{l}32 \\
, 1\end{array}$ & 19 & $\begin{array}{r}67 \\
, 9\end{array}$ & 28 & 100 & & \\
\hline
\end{tabular}

Based on Table 9, the percentage of LBWB was higher in mothers with anemia status $(67.9 \%)$ compared with non-anemia status (38.6\%). Statistically there was a significant relationship $(\mathrm{p}<0.05)$ between anemia status and the incidence of LBWB. Contingency coefficient value is 0.274 which shows that the relationship between variables is weak.

Table 10. The Relationship between the Implementation of Antenatal Care and the Incidence of Low Birth Weight Babies

\begin{tabular}{|c|c|c|c|c|c|c|c|c|}
\hline \multirow{2}{*}{$\begin{array}{c}\text { The } \\
\text { Impleme } \\
\text { ntation } \\
\text { of } \\
\text { Antenat } \\
\text { al Care } \\
\end{array}$} & \multicolumn{2}{|c|}{$\begin{array}{c}\text { NBW } \\
\text { B }\end{array}$} & & NB & \multicolumn{2}{|c|}{ Total } & \multirow[b]{2}{*}{$\mathbf{p}$} & \multirow[b]{2}{*}{ C } \\
\hline & $\mathbf{f}$ & $\%$ & f & $\%$ & f & $\%$ & & \\
\hline Poor & $\begin{array}{l}1 \\
2\end{array}$ & $\begin{array}{l}30 \\
8\end{array}$ & 27 & $\begin{array}{l}69 \\
, 2\end{array}$ & 39 & 100 & $\begin{array}{c}0,0 \\
00\end{array}$ & $\begin{array}{l}0,3 \\
86\end{array}$ \\
\hline Good & $\begin{array}{l}2 \\
4\end{array}$ & $\begin{array}{r}72 \\
, 7\end{array}$ & 9 & $\begin{array}{l}27 \\
, 3\end{array}$ & 33 & 100 & & \\
\hline
\end{tabular}

Based on Table 10, the percentage of LBWB was higher in mothers with poor implementation of antenatal care $(69.2 \%)$ compared to mothers with good antenatal care $(27.3 \%)$. Statistically there was a significant relationship $(\mathrm{p}<0.05)$ between the implementation of Antenatal Care and the incidence of LBWB. Contingency coefficient value is 0.386 which shows that the relationship between variables is weak.
Table 11. The Relationship between the Quality of Antenatal Care Services and the Incidence of Low Birth Weight Babies

\begin{tabular}{|c|c|c|c|c|c|c|c|}
\hline \multirow{2}{*}{$\begin{array}{c}\text { The } \\
\text { Quality of } \\
\text { Antenatal } \\
\text { Care } \\
\text { Services }\end{array}$} & \multicolumn{2}{|c|}{ NBWB } & \multicolumn{2}{|c|}{ LBWB } & \multicolumn{2}{|c|}{ Total } & \multirow[b]{2}{*}{$\mathbf{p}$} \\
\hline & f & $\%$ & f & $\%$ & $\mathbf{f}$ & $\%$ & \\
\hline Poor & 16 & $\begin{array}{r}51 \\
, 6\end{array}$ & 15 & $\begin{array}{r}48 \\
, 4\end{array}$ & 31 & 100 & $\begin{array}{c}0,81 \\
2\end{array}$ \\
\hline Good & 20 & $\begin{array}{r}48 \\
, 8\end{array}$ & 21 & $\begin{array}{r}51 \\
, 2\end{array}$ & 41 & 100 & \\
\hline
\end{tabular}

Based on Table 11, the percentage of LBWB was higher in the good quality of Antenatal Care services (51.2\%) compared to the poor quality of Antenatal Care services (48.4\%). Statistically there was no significant relationship ( $p>0.05$ ) between the quality of Antenatal Care services at health facilities level I and the incidence of LBWB.

Table 12. The Results of Multivariate Logistic Regression Analysis

\begin{tabular}{|c|c|c|c|c|}
\hline & Variable & B & $\mathbf{p}$ & $\begin{array}{c}\text { OR(CI } \\
95 \%) \\
\end{array}$ \\
\hline \multirow{11}{*}{ Step 1} & Pregnancy & & & 0,59 \\
\hline & Complicatio & - & 0,40 & $(0,177-$ \\
\hline & $\mathrm{n}$ & 0,518 & 2 & $2,003)$ \\
\hline & & & & 0,82 \\
\hline & Anemia & - & 0,78 & $(0,215-$ \\
\hline & Status & 0,190 & 1 & $3,174)$ \\
\hline & The & & & 4,76 \\
\hline & Implementat & & 0,00 & $(1,506-$ \\
\hline & ion of ANC & 1,561 & 8 & $15,075)$ \\
\hline & & - & 0,44 & \\
\hline & Constanta & 0,502 & 0 & 0,60 \\
\hline \multirow{8}{*}{ Step 2} & Pregnancy & & & 0,54 \\
\hline & Complicatio & - & 0,26 & $(0,190-$ \\
\hline & $\mathrm{n}$ & 0,602 & 4 & $1,577)$ \\
\hline & The & & & 5,08 \\
\hline & Implementat & & 0,00 & $(1,762-$ \\
\hline & ion of ANC & 1,626 & 3 & $14,678)$ \\
\hline & & - & 0,21 & \\
\hline & Constanta & 0,616 & 9 & 0,54 \\
\hline \multirow{5}{*}{ Step 3} & The & & & 6,00 \\
\hline & Implementat & & 0,00 & $(2,154-$ \\
\hline & ion of ANC & 1,792 & 1 & $16,712)$ \\
\hline & & - & 0,01 & \\
\hline & Constanta & 0,981 & 2 & 0,37 \\
\hline
\end{tabular}

Based on Table 12 it can be seen that out of the 3 variables analyzed, the variable of implementation of Antenatal Care was the dominant variable associated with the incidence of LBWB, with $\mathrm{p}=0.001$ and OR 
$=6.00$. OR (Odds Ratio) value states that the tendency of respondents with poor implementation of Antenatal Care are 6 times greater to have LBWB than respondents with good implementation of Antenatal Care.

\section{DISCUSSION}

\section{The Correlation of Maternal Age with the Incidence of Low Birth Weight Babies}

The results of this study are in line with the study ofKanjanasingh's (2013) that there was no relationship between maternal age and Low Birth Weight Babies with $\mathrm{p}=0.68$ ( $\mathrm{p}$ > 0.05). Purwanto (2016) in his study also mentioned that from Fisher's Exact test results obtained $\mathrm{p}$ value $=0.272(\mathrm{p}>0.05)$ so it was concluded that there was no relationship between the age of the mother during pregnancy and the incidence of LBWB. In addition, Pramono (2009) also obtained the same results that there was no significant relationship between maternal age and the incidence of LBWB which was known from $p=0.65$ ( $p>0.05$ ) with a percentage of maternal age $<20$ years or $>35$ year is higher $(4.9 \%)$ compared to maternal age $20-35$ years $(4.7 \%)$.

Based on the results of this study, it is also known that LBWB can occur in mothers with an age that is not at risk of $47.3 \%$. This shows that mothers who are pregnant at an age that is not at risk are not necessarily healthy fetal growth in the womb, because one of them can be influenced by the level of knowledge possessed by the mother, especially knowledge about how to care for pregnancy. Someone who has good knowledge about health tends to behave healthily. By providing knowledge to the community through counseling, especially to pregnant women, it is expected to increase their knowledge, especially in an effort to prevent the occurrence of LBWB. If someone has less knowledge about how to care for the correct pregnancy, the need for the fetus and mother will not be fulfilled properly. As a result, the mother will experience health problems that affect her pregnancy, as for mothers who experience anemia will have an impact on the fulfillment of nutrients to the fetus, which will interfere with fetal growth. Therefore, aside from health workers, family support is also needed to motivate mothers to be able to care for their pregnancies properly, so that mothers are far from the risk of LBW.

\section{The Relationship of Parity with the Incidence of Low Birth Weight Babies}

The results of this study are in line with the study of Sistiarani (2008), that there is no significant relationship between parity to the incidence of LBWB and parity in not a risk factor for LBWB incidence with a value of $p$ $=0.397$. In contrast to the study of Gebremariam(2005) which states that parity shows a negative relationship with LBWB. Gebremariam's findings show that the higher the parity, the lower the chance of having low birth weight babies, so it was concluded that there was a relationship between parity and low birth weight $(\mathrm{p}=0,000)$.

In this study, the incidence of LBWB had the same comparison between mothers with low parity and mothers with high parity. Based on these results it can be explained that both mothers who are classified as low or high parity have the same opportunity to give birth to LBWB. This is influenced by maternal behavior in maintaining health, so that it has an impact on maternal and fetal health conditions. Mothers who do not understand how daily care during pregnancy and the nutritional needs needed for fetal growth and development will be more at risk of getting health problems than mothers who can care for their pregnancies properly.

\section{The Relationship Between Pregnancy Distance and the Incidence of Low Birth Weight Babies}

This study is in line with the study of Purwanto (2016) which states that between the distance of pregnancy and the incidence of LBWB does not have a significant relationship ( $p=0.418)$. This shows that the 
distance of pregnancy is not at risk for the incidence of LBWB. The cases of LBWB that occur can be caused by other factors such as the presence of a disease experienced by the mother during pregnancy.

In this study, the incidence of LBWB had a similar comparison between mothers at risk of pregnancy and mothers with a pregnancy were not at risk. Based on these results it can be explained that both mothers who are classified as risk or not at risk based on the distance of pregnancy, have the same opportunity to give birth to LBWB. In addition, the distance of pregnancy is also not a major factor causing LBWB. The cases of LBWB that occur may be due to an abnormal presentation or chronic vascular disease experienced by the mother. This is a risk factor for fetal growth disorders, especially if pregnancy is accompanied by complications such as preeclampsia. Preeclampsia can cause fetal growth failure and is an indicator of chronic vascular disease, especially if it occurs before 37 weeks' gestation. In a study, it was stated that vascular disease in early pregnancy can cause an increase in the rate of preeclampsia, a small neonate during pregnancy and birth before 34 weeks (Cunningham et al, 2012).

\section{The Relationship of Pregnancy Complications with the incidence of Low Birth Weight Babies}

This study is in line with study conducted by Sistiarani (2008), that there is a significant difference in LBWB percentage between mothers who have disease during pregnancy with mothers who do not have disease during pregnancy with a value of $\mathrm{p}=0.03(\mathrm{p}<0.05)$. Risk factor analysis found OR $=2.91(95 \%$ CI: 1.1 - 8.2) meaning that mothers who experienced the disease during pregnancy had the opportunity to give birth to LBWB is 2.91 times compared to mothers who did not experience the disease during pregnancy. The types of diseases found in the study were hypertension, hypotension, preeclampsia, eclampsia, protein energy deficiency (PEM), heart disease, tuberculosis and anemia.

Based on the results of this study, to detect early complications that might occur in pregnant women, it is suggested that mothers care more about making a visit in early pregnancy, namely in the first trimester, so that mothers will be better prepared to undergo pregnancy by knowing how to take care of the day. day and can handle complications that may be encountered in pregnancy. In addition, according to Hailu (2017) the signs and symptoms of pregnancy complications are indicative of several disorders during pregnancy which can have a negative impact on the baby's birth weight. It is therefore recommended that pregnant women should be aware of danger signs during pregnancy and the possible causes of complications during pregnancy must be quickly known and managed properly. Thus, routine antenatal care performed by pregnant women can help for early detection and appropriate management of the disorder during pregnancy.

\section{The Relationship of Economic Status with the Incidence of Low Birth Weight Babies}

The results of this study are in line with the study of Nuryani (2017) which shows that there is no association between the incidence of LBWB and monthly family income $(\mathrm{p}=$ 0.709). Mahayana et al. (2015) also stated that there was no significant relationship between the incidence of LBWB and socioeconomic status $(\mathrm{p}=0.990)$.

In this study, the results of the study were not supported by existing theories. This is because there are still other factors that influence the incidence of LBWB, meaning that economic status is not a single factor causing LBWB. The low economic status in this study is influenced by the work of the respondents in which $80.6 \%$ of the respondents who have LBWB are more dominant as housewives and their husbands work as laborers, so that their income is unstable. 
The Relationship between Nutritional Status with the Incidence of Low Birth Weight Babies

The results of this study are in line with the study of Andarbeni's (2013) which showed that there was no relationship between upper arm circumference and birth weight with $\mathrm{p}=$ 0.487. In addition, Putri (2015) also stated that there was no significant relationship between Chronic Energy Deficiency (CED) and the incidence of LBWB. The proportion of women of childbearing age (WUS) with SEZ, namely WUS with upper arm circumference (LILA) less than $23.5 \mathrm{~cm}$.

In this study, although there was no statistical relationship between nutritional status and the incidence of LBWB, it was seen from the incidence rate of LBWB more prevalent in respondents with less nutritional status $(63.6 \%)$ than in good nutritional status (47.5\%). In addition, in this study only assessing nutritional status of maternal LILA size and weight gain during pregnancy is not a concern so mothers with good nutritional status in terms of measuring LILA, based on the results of this study can also give birth to babies with LBWB of $47.5 \%$. Therefore, apart from LILA, the need for an assessment of maternal weight gain during pregnancy because it will affect the nutritional needs of both mother and fetus. This is because according to Supariasa (2001), in order to measure nutritional status in addition to measuring LILA, there are still other parameters that are used including measuring body weight.

\section{The Relationship of Anemia Status with the Incidence of Low Birth Weight Babies}

The results are in line with the study of Asiyah's (2011) which states that anemia in pregnant women can result in reduced oxygen supply to the tissues and will interfere with fetal growth so that it will strengthen the risk of giving birth to LBWB. Purwanto (2016) also stated that mothers with $\mathrm{Hb}$ levels were at risk of having a 20.907 times greater chance of delivering
LBWB than mothers with $\mathrm{Hb}$ levels not at risk.

If the $\mathrm{Hb}$ level is lacking in the blood, the ability of the blood to bind and carry oxygen will decrease, as well as the nutrients carried by red blood cells will also be reduced. Lack of $\mathrm{Hb}$ levels causes the blood to not be able to send enough oxygen to the entire network, so that the metabolic process and the exchange of important nutrients in the tissues are disrupted. This condition will affect the mother and fetus they contain. Lack of absorption and transportation of oxygen to various body tissues causes reduced supply of food to the fetus through the placenta so that the placenta becomes small and the transfer of nutrients to the fetus is needed for development and reduced fetal growth. This condition causes the slow growth of the fetus so that the baby's weight is born low because the placenta is the main source of fetal food (Purwanto, 2016). In this study, the OR value $=3.35(95 \%$ CI: 1,235 - 9,102), meaning that nutritional status is a risk factor for LBWB causes.

\section{The Relationship between the Implementation of Antenatal Care and the Incidence of Low Birth Weight Babies}

This study is in line with the study of Kanjanasingh's (2013) which states that good antenatal care is related to LBWB. Good antenatal care is when you visit at least 1 time in the first and second trimesters, and 2 times in the third trimester. Thus, the risk or problem in pregnancy can be detected early and prevent the occurrence of LBWB. Mothers who do not receive antenatal care will be more likely to deliver LBWB babies than mothers who receive antenatal care, where $\mathrm{OR}=4.3(95 \% \mathrm{CI}=2.6-7.3)$ which means that mothers who do not receive antenatal care 4, 3 times more at risk of LBWB in women receiving antenatal care.

In this study, the number of respondents with poor implementation of antenatal care was caused by many who did not conduct antenatal visits according to the recommended minimum standards, and even 
$50 \%$ of mothers who had LBWB did not make an initial visit in the first trimester during their pregnancy. Therefore, maternal $\mathrm{K} 1$ is no longer pure $\mathrm{K} 1$, but it is $\mathrm{K} 1$ access, namely the first visit outside the first trimester during pregnancy which is conducted in the second trimester or in the third trimester. Therefore, the need to increase awareness of couples of childbearing ages to have a prenatal checkup as early as possible from the very first to know that the mother knows she is pregnant.

The Relationship between the Quality of Antenatal Care Services and the Incidence of Low Birth Weight Babies

This study was supported by the study of Pinzon-Rondon (2015), which states that the quality of prenatal care had no relationship with the incidence of LBWB ( $p=0.076)$. In addition, it is also in line with the study of Reza (2014) which states that there is no relationship between the quality of ANC and the incidence of LBWB $(\mathrm{p}=0.244)$.

In this study, the large number of respondents in LBWB cases who received good quality antenatal care services $(51.2 \%)$ compared to the poor quality of antenatal care services (48.4\%). This can be influenced by the behavior of the mother, such as adherence to taking blood-added tablets and scheduled visits to health workers. Tablets added blood (iron substance tablets) and Folic Acid given to mothers at least 90 tablets during pregnancy are not consumed according to the rules, so mothers are prone to anemia. The percentage of mothers who experienced anemia in LBWB cases was found to be $67.9 \%$. Likewise, with mothers who do not visit according to their recommendations, the possibility of complications in pregnancy will not be detected early. This can be seen from the still high percentage of mothers with poor antenatal care while the facilities visited were relatively good, which amounted to $76.2 \%$ of mothers who had LBWB.

\section{The Dominant Factors Affecting the Incidence of Low Birth Weight Babies}

Based on the results of the study, it can be concluded that from several maternal factors studied, the implementation of antenatal care is very important for pregnant women, because it has many benefits, especially in monitoring the condition of maternal pregnancy to run properly and normally. In addition to the routine mother carries out Antenatal Care, can avoid the factors that cause birth of babies with abnormal weight (LBWB).

\section{CONCLUSION}

The implementation of antenatal care is the dominant variable associated with the incidence of Low Birth Weight Babies (LBWB).The need to conduct Antenatal Care regularly in order to avoid complications in pregnant women who will be at risk in pregnancy. 


\section{REFERENCES}

Ahankari, A. d.-B. (2014). Maternal Hemoglobin and Birth Weight : Systematic Review and Meta-Analysis. International Journal of Medical Science and Public Health 2015 Vol. 4.

Apriliani, R. A. (2015). Pengaruh Yoga Prenatal Terhadap Kecemasan Sesaat Dalam Menghadapi Persalinan Pada Primigravida Trimester Iii Digalenia Mom And Baby Center Kota Bandung. Prosiding Psikologi Universitas Islam Bandung.

Bobak dkk. (2005). Buku Ajar (Keperawatan Maternitas - Edisi 4). Jakarta: EGC.

Cunningham et al. (2012). Obstetri Williams Vol.2. Jakarta: EGC.

Cunningham et al. (2013). Neonatology Seventh Edition. USA: Mc Graw-Hill Education.

DepKes. (2010). Pedoman Pemantauan Wilayah Setempat Kesehatan Ibu dan Anak. Jakarta: DepKes.

Depkes RI. (2007). Pedoman Pelayanan Antenatal. Jakarta: Depkes RI.

Depkes RI. (2007). Pelatihan Pelayanan Obstetri dan Neonatal Emergensi Dasar. Jakarta: Depkes RI.

Depkes RI. (2007). Pelayanan Obstetri Neonatal Emergensi Dasar. Jakarta: Depkes RI.

Dewi dan Sunarsih. (2011). Asuhan Kehamilan Untuk Kebidanan. Jakarta: Salemba Medika.

DinKes Kota Padang. (2015). Profil Kesehatan Kota Padang. DinKes.

DinKes Kota Padang. (2016). Profil Kesehatan Kota Padang. Padang: Dinkes Kota Padang.

Dinkes Kota Padang. (2016). Profil Kesehatan Kota PadangTahun 2016. Padang: Dinkes.

DinKes Kota Padang. (2017). Laporan Tahunan Tahun 2016. Padang: DinKes Kota Padang.

Dinkes Kota Padang. (2017). Profil Kesehatan Kota PadangTahun 2016. Padang: Dinkes.

DinKes Provinsi Sumbar. (2015). Profil Kesehatan Provinsi Sumatera Barat.

Eissa et al. (2017). The Correlation Between Maternal Hemoglobin Level and Neonatal Birth

Weight. International Journal of Multidisciplinary and Current Research Vol. 5.

Elfindri, dkk. (2012). Metodologi Penelitian Kesehatan. Jakarta: Baduose Media Jakarta.

Husein, S. (2014). Pengaruh Antenatal care terhadap kejadian Berat Bayi Lahir Rendah (BBLR). Jurnal Biometrika dan Kependudukan, Vol.3 No.2 Desember 2014 : 160-167.

IDAI. (2009). Pedoman Pelayanan Medis IDAI. IDAI.

IDAI. (2009). Pedoman Pelayanan Medis Ikatan Dokter Anak Indonesia. Jakarta: IDAI.

Indrasari, N. (2012). Faktor Resiko Pada Kejadian Berat Badan Lahir Rendah (BBLR) No. 2.

Bandar Lampung : Poltekkes Kemenkes Tanjung Karang. . Jurnal Keperawatan, Volume VIII, No. jalan Bandar Lampung .

Kanjanasingh, et al. (2013). The Association between Antenatal Care and Low Birth weight

Newborn at Bhumibol Adulyadej Hospital Thailand. Royal Thai Air Force Medical

Gazette, Vol.59 No.2.

Karwati dkk. (2011). Asuhan Kebidanan V (Kebidanan Komunitas). Jakarta: Trans Info Media.

Karwati, dkk. (2011). Asuhan Kebidanan V (Kebidanan Komunitas). Jakarta: Trans Info Media.

Kemenkes RI. (2010). Riset Kesehatan Dasar Indonesia 2010. Jakarta: Badan Penelitian dan Pengembangan Kesehatan.

Kemenkes RI. (2016). Profil Kesehatan Indonesia Tahun 2015. Jakarta: Kemenkes RI.

Khatun S. (2007). Quality of antenatal care and its dose-response relationship with birth weigh in a maternal and child health training institute in Bangladesh.

Khatun S, M Rahman. (2007). Quality of antenatal care and its dose-response relationship with birth weigh in a maternal and child health training institute in Bangladesh.

Kosim, M. S. (2014). Buku Ajar Neonatologi Edisi Pertama. Jakarta: IDAI.

Maryanti, Dwi, dkk. (2011). Buku Ajar Neonatus, Bayi dan Balita. Jakarta: Trans Info Media. 
Monita dkk. (2016). Hubungan Usia, Jarak Kelahiran dan Kadar Hemoglobin Ibu hamil dengan Kejadian Berta BAyi Lahir Rendah Di RSUD Arifin Achmad Provinsi Riau. Jom FK Vol.3 No.1.

More, J. (2013). Gizi Bayi, Anak dan Remaja. Yogyakarta: Pustaka Pelajar.

Mukhadiono. (2011). Pengaruh Prosedur dan Fasilitas Pelayanan Terhadap Kualitas Pelayanan Peserta Program Jamkesmas di Puskesmas I Cilongok. Jurnal Keperawatan Soedirman (The Soedirman Journal of Nursing), Volume 6, No.1, Maret 2011.

Nelson W, dkk. (2000). Ilmu Kesehatan Anak Nelson Ed 15 Vol 1. Jakarta: EGC.

Notoatmodjo. (2003). Pendidikan dan Perilaku Kesehatan. Jakarta: Rineka Cipta.

Notoatmodjo. (2010). Ilmu Perilaku Kesehatan. Jakarta: Rineka Cipta.

Notoatmodjo, S. (2010). Metodologi Penelitian Kesehatan. Jakarta: Rineka Cipta.

Nugroho, dkk. (2012). Asuhan kebidanan I. Yogyakarta: Nuha Medika.

Nursaputri, S. (2015). Analisis Faktor-Faktor yang Berhubungan dengan Kejadian Bayi Berat Badan Rendah Pada Wanita Hipertiroid Kehamilan Di Kabupaten Magelang. Semarang: UNNES.

Pantiawati, I. (2010). Bayi dengan BBLR. Yogyakarta: Nuha Medika.

Peraturan Pemerintah RI No. 47 . (2016). Fasilitas Pelayanan Kesehatan .

Permenkes RI. (2013). Pelayanan Kesehatan Pada Jaminan Kesehatan Nasional.

Permenkes RI. (2016). Standar Pelayanan Minimal Bidang Kesehatan.

Pinzon-Rondon et al. (2015). Low Birth Weight and Prenatal Care in Colombia. BMC Pregnancy and Childbirth, 15:118.

PPIDAI. (2009). Pedoman Pelayanan Medis IDAI . IDAI.

Prawirohardjo. (2006). Ilmu Kebidanan. Jakarta: YBP-SP.

Prawirohardjo. (2009). Ilmu Kebidanan. Jakarta: YBP-SP.

Prawirohardjo, S., \& Wiknjosastro, H. (2006). Ilmu Kebidanan. Jakarta: YBP-SP.

Prawirohardjo, S., \& Wiknjosastro, H. (2009). Ilmu Kebidanan. Jakarta: YBP-SP.

Purwanto, A. D. (2016). Hubungan antara Umur Kehamilan, Kehamilan GAnda, Hipertensi dan Anemia dengan Kejadian Bayi Berat Lahir Rendah (BBLR). Surabaya: FKM UA.

Rasyid, P. S. (2012). Faktor Risiko Kejadian Bayi Berat Lahir Rendah Di RSUD Prof. Dr. H. Aloei Saboe Kota Gorontalo Provinsi Gorontalo Tahun 2012, Tesis. Universitas Hassanuddin.

Riskesdas. (2013). Profil Kesehatan Indonesia. Kemenkes RI.

Rudolph, A. M. (2006). Buku Ajar Pediatri Rudolph Ed.20 Vol.1. Jakarta: EGC.

Saifuddin, A. (2007). Buku Acuan Nasional Pelayanan Kesehatan Maternal Dan Neonatal. Jakarta: Yayasan Bina Pustaka Sarwono Prawirohardjo.

Sandra Surya Rini, I. T. (2013). Faktor - faktor resiko kejadian Berat Bayi Lahir Rendah di wilayah kerja unit pelayanan terpadu Kesmas Gianyar II. Bagian Ilmu Kesehatan Anak FK UNUD.

Sastroasmoro, S. d. (2011). Dasar - Dasar Metodologi Penelitian Klinis. Jakarta: Sagung Seto.

Simarmata, O. S. (2010). Hubungan Kualitas Pelayanan Antenatal Terhadap Kejadian Bayi Berat Lahir Rendah di Indonesia (Analisis Data Sekunder Survei Demografi dan Kesehatan Indonesia 2007). Depok: FKM UI.

Sistiarani, C. (2008). Faktor Maternal dan Kualitas Pelayanan Antenatal yang Beresiko Terhadap Kejadian Berat Badan Lahir Rendah (BBLR). Semarang: Universitas Diponegoro.

Sondakh dkk. (2013). Mutu Pelayanan Kesehatan dan Kebidanan. Jakarta: Salemba Medika. Sugiyono. (2008). Metode Penelitian Kuantitatif, Kualitatif dan R\&D. Bandung: Alfabeta.

Sulistyawati, A. (2009). Asuhan Kebidanan Pada Masa Kehamilan. Jakarta: Salemba Medika.

Supariasa dkk. (2001). Penilaian Status Gizi. Jakarta: EGC.

Supariasa, I. D., \& dkk. (2001). Penilaian Status Gizi. Jakarta: EGC. 
Suwarni, Y. (2012). Hubungan antara Paritas, LiLa, Kadar HB dan Usia Ibu Hamil dengan Berat Lahir Bayi. Banjarbaru: FK Unlam.

Syarif, S. (2012). Telaah Model Peningkatan Kualitas Program Kesehatan Ibu, Bayi Baru Lahir dan Anak (KIBBLA). MCHIP.

UNICEF Indonesia. (2012). Kesehatan Ibu dan Anak. UNICEF.

WHO. (2014). GLobal Nutrition Targets 2025: Low Birth Weight Policy Brief (WHO/NMH/NHD/14.5). Geneva: World Health Organization.

Yildiz et al. (2013). The relationship between third trimester maternal hemoglobin and birth weight/length; results from the tertiary center in Turkey. The Journal of Maternal-Fetal \& Neonatal Medicine Informa UK Ltd. DOI: 10.3109/14767058.2013.837445. 